\title{
Adorno: Cultural Education and Resistance
}

\author{
Sharon Jessop ${ }^{1}$ iD
}

Published online: 14 September 2016

(C) The Author(s) 2016. This article is published with open access at Springerlink.com

\begin{abstract}
In recent years, culture has become significantly politicized, or conspicuously de-politicized, in different parts of the UK, making its appearance in education policy of pivotal interest and ripe for critical attention. From the vantage point of Theodor Adorno's work on the culture industry and his writings on the work of the teacher, I argue that cultural education is a site where something crucial and distinctive takes place. Within the Enlightenment tradition, critical self-reflection and resistance to heteronymous ways of thinking are core aims of education. Adorno's contribution to an understanding of these aims leads us to consider the importance of 'live contact with the warmth of things' as essential to ethical and intellectual life. The kindly tolerance of the pluralist ideal is now being teased and goaded by acts of terror and widespread concern about personal and social security. At such an unstable juncture, an understanding of cultural education as an experience of 'incorrigible plurality' enriches and informs the beleaguered ideal of pluralism and points a way forward in troubled times.
\end{abstract}

Keywords Adorno $\cdot$ Culture $\cdot$ Cultural education $\cdot$ Pluralism

The room was suddenly rich and the great bay-window was

Spawning snow and pink roses against it

Soundlessly collateral and incompatible

World is suddener than we fancy it

World is crazier and more of it than we think,

Incorrigibly plural. I peel and portion

The tangerine and spit the pips and feel

Sharon Jessop

s.jessop@strath.ac.uk

1 School of Education, University of Strathclyde, Lord Hope Building, 141 St James Road, Glasgow G4 OLT, UK 
The drunkenness of things being various.

The fire flames with a bubbling sound for world

Is more spiteful and gay than one supposes -

On the tongue on the eyes on the ears in the palms of one's hands -

There is more than glass between the snow and the huge roses.

Louis MacNeice 'Snow' 1935

\section{Introduction}

This article offers a hermeneutical approach to education policy in relation to arts and culture, informed by the work of Theodore Adorno on the culture industry and in his aesthetic theory. I begin with a detailed account of recent policy trends in cultural education, using a comparison between two divergent contexts to illustrate where choices have been made that reflect differing political and social priorities. The aim is to provide an interpretation and understanding of the significance of these choices for the educational project and to point to the particular opportunities presented by cultural education.

\section{UK Policy on the Arts and Education}

None of the four countries of the UK is a state in its own right, but the separation of nationhood and statehood has had a different effect on the cultural self-understanding of each country because of the different ways in which each entered, or was brought, into the Union, their relative size and their relationships to the centres of power. The political import of culture policy has become increasingly evident in recent years as the underpinning principles of different devolved UK administrations diverge.

With no political locus until the establishment of the devolved parliament in 1999, Scotland has been anxious about identity and culture for a long time. One widely held opinion is that the cultural production of the people who live in Scotland has been systematically suppressed and ignored by successive UK institutions, leading to a marked lack of self-belief (Beveridge and Turnbull 1989; Craig 2003; Moffat and Riach 2014). This might be stony ground for a new curriculum that seeks to couple culture and history with a view to fostering exploration, reflection and the solving of problems (Education Scotland 2013, p. 2). However, culture features prominently in plans for the country's future. Successive Scottish administrations have seen cultural activity as a key concern as expressed in a quite phenomenal number of government strategies, reports and commissioned studies over the past few years. Public discussion has been vigorous and occasionally acrimonious, but a general approach is emerging which strongly suggests an understanding of the value of cultural activity that is highly distinctive in the UK context. Illustrative of this claim is the discourse surrounding the policies of certain government departments and agencies in the last couple of years.

At the end of 2013, the chief executive of Creative Scotland resigned after months of criticism from the arts community. The organization, which is the development agency with responsibility for the distribution of public funds for the arts, was accused of being infected with 'a kind of undead Thatcherism, a half-baked, hollowed-out, public sector version of market theory that reduces the language of creativity to a series of flat-footed business school slogans, and imposes a crude ethic of sado-competition' (McMillan 2012). 
An open letter from 100 prominent artists and writers followed in October 2012 criticizing, amongst other things, the dominance of commercial values over those that are social and cultural in Creative Scotland's policies (Herald 2012). The idea of 'creative enterprise' was vigorously challenged by an artistic community that rejected its re-designation as a unit of economic production.

In June 2013, following this public embarrassment, the Scottish culture secretary gave a speech in which she strongly asserted the distinctive nature of her government's approach. In this, she says that 'culture and heritage have value in and of themselves... because they are our heart, our soul, our essence'. The economic value of culture 'is not its primary purpose but a secondary benefit' (Hyslop 2013). In quite startling contrast, the then English Culture Secretary described funding for the arts as 'venture capital' in a speech given in April 2013. The purpose of the speech, she said, was to 'hammer home the value of culture to our economy.... Our focus must be on culture's economic impact' (Miller 2013). In the face of this hard-faced neoliberalism, even the Chair of the Arts Council in England explicitly abandoned any attempt to communicate her belief that 'culture is a deep necessity to human beings' because 'politicians aren't interested in that' (Forgan 2013). In both nations, the arts are struggling with an economic agenda that threatens their existence; but, for the artistic community in Scotland there are stronger grounds for, very cautious, optimism.

The economic utility of culture complements its political utility. The current administration in Scotland is formed by the Scottish National Party in the most volatile UK political scene since Margaret Thatcher's era, a fact which might colour our understanding of the motivations behind some government backing for the arts, since: 'to conceive of Scotland as a globally networked population of 40 million people is arguably a more powerful way to think. It is clear that a strong cultural attachment to Scotland is a prerequisite for all other efforts to engage diasporic groups' (Ancien et al. 2009, p. 28). A question that needs to be asked is how an outward-facing cultural event will affect the way in which those on the inside, as it were, think about themselves in terms of their cultural identity or identities. In other words, what is the effect of commodification on 'intangible cultural heritage'? (McCleery et al. 2008, p. 10). One obvious effect might be a bias to the 'traditional' meaning a selection of indigenous art forms. This potentially distorts cultural activity in a plural society in a way that contradicts government pronouncements and presents the danger of a nostalgic cultural necromancy from which Scotland has only recently emerged.

\section{Culture in Education Policy}

The growing importance of cultural issues in the broader policy context is also reflected in educational discourse. Striking changes have taken place over the past two decades in terms of the frequency of use and also the context in which the term appears.

Education policy in Scotland is formed by means of a distinctive process of consultation, dispersal and consensus. The main programmatic statement for the school curriculum, 'The Structure and Balance of the Curriculum', in place between 1993 and 2010, lays out the foundational principles and aspirations of the curriculum as a whole. Between the 1993 and 2000 editions of this document, the number of times the term 'culture' appears in some form triples, partly due to the introduction of 'The culture of Scotland' as a cross-curricular aspect. In 2006, a new curriculum was proposed and the principles were laid out in A Curriculum for Excellence: Building the Curriculum 3-18 (1), in which the number of 
times 'culture' or 'cultural' appears almost triples again. Alongside this, there is, for the first time, mention of cultural identity and a very strong emphasis on Scotland. A subsequent guidance document: 'Building the Curriculum 3' advises: 'Children and young people are entitled to a broad general education.... Throughout this broad curriculum it is expected there will be an emphasis on Scottish contexts, Scottish cultures and Scotland's history and place in the world' (2008, p. 5). 'Learning about Scotland' lays out in more detail the ways in which the emphasis is to be achieved asserts the 'entitlement for children and young people to learn about Scotland's cultures, people, history, achievements and languages' (Education Scotland 2013).

Whilst the Scottish curriculum has rapidly been gaining confidence in using the idea of culture as a way of life and attempting to negotiate the difficulties involved in asserting Scottish history and culture in a plural society, two major documents that have been published south of the border indicate a strongly contrasting trend. The English National Curriculum (2013) contains curiously little reference to culture, except in the context of Design and Technology and in two instances where 'other/different cultures' are mentioned. There is a reference to 'cultural development' through the literature and a nonspecific reference to cultural history. There is not a single reference to English culture or history, though there are numerous references to British history (DfE 2013, p. 165). The general picture is that the concept of culture features very little and English culture, history and identity are conspicuous only by their absence.

In 2012, a government commissioned review, 'Cultural Education in England' was published. Its author, Darren Henley, interprets the term 'culture' in the sense of creative endeavour: performance and expressive arts and design and the literature, thus apparently avoiding the difficulties of talking about culture as also a way of life in a plural society. However, the neutrality of culture as intellectual and artistic endeavour is deceptive. This detailed 84-page report at no stage acknowledges the existence of anything other than a unitary cultural heritage, though it does say in an oddly and somewhat anachronistically worded statement that:

Children of all races and genders should be able to connect to the Cultural Education that they receive. It is important that no minority groups are forgotten in any strategy changes that take place as a result of this Review. (Henley 2012, p. 14)

Despite the lack of explicit 'Englishness' in this review of cultural education in England, it seems that 'minority groups' are something of an afterthought. The thinking behind this omission is a moot point. There are different ways of responding to the challenges of a plural society and, considering the cultural and linguistic commonalities in the UK, it might be surprising that the emphases in education policy are so markedly distinct.

The Scottish and English policy frameworks do not overlap in their application and are not directly in conversation with one another, but the language nonetheless is a site of struggle. The absence of markers of national identity from discussion in English education results in a simulated sameness, which hides certain historical hierarchical relations between the countries of the UK. Though the ideological projection of English identity as British, and therefore normal, may in some ways protect power interests, it is not obvious that this silence on English culture, history and identity will serve the individual or social development of the English people. Contemporary discourse on culture takes place in full view of politically and ethically contentious territory. It is imperative to distance policy on cultural education from narrowly nationalistic, exclusive, discriminatory or parochial associations, but complete silence on the topic dangerously and disingenuously creates a void, which will be filled by voices peddling precisely this ideology. Current difficulties 
being experienced in parts of the English education system are the result of policies that have permitted monocultural schooling, given isolationist minority parental groups freedom to exert strong influence on teaching and the curriculum, and, by inevitable corollary, lessened local government supervision. A recent government commissioned investigation into Birmingham schools found that an unrepresentative group of parents were able to take key positions on school boards. Amongst their 'achievements' in certain schools were the elimination of arts and humanities from the curriculum and the promotion of intolerance of difference and diversity. This went unchallenged by the local council in order to protect 'community cohesion' (Clark 2014). Neoliberal governance without discussion of English identities is creating social and political divisions, which will be increasingly difficult to put right.

Despite their many similarities, Scotland and England are currently tracing very different paths in respect of their approaches to culture and to cultural education. Rejection by the creative community in Scotland of their designation as mere commodity suggests a self-conception that is strongly resonant with Adorno's theory of culture: the hope of a not completely reified culture which protects the possibility of social and political critique, aligned with the dialectical vigour of pluralism.

\section{Adorno and Culture}

Scrutiny of Theodor Adorno's concept of culture and his understanding of the role of the teacher yields important insights into how cultural education is at the core of educational practice. Adorno is one of the twentieth century's foremost critics of modernity and is

well known for his application of Marxism to the conditions of late capitalism, and in particular culture. He is not a writer whose work can be easily 'applied', nor did he wish it to be. His work is anti-systematic, often incomplete, and fragmentary: he would not give the reader the satisfaction of a completed argument because that is the very means by which we are dominated, an idea that is central to his critique of culture itself. The unity of form and content in Adorno's writing is similar to that of Walter Benjamin with whom he shared fundamental ethical, theological, political and philosophical commitments. ${ }^{1}$ An utterly complete and consistent totality, or the aim to achieve one in argument, is what he regarded as a Nazi aesthetic. His writing is intentionally fragmented and empirically impressionistic. This is not the same as falling backwards into a mystical irrationalist world view; certainty can be a sign that you have, in fact, stopped thinking. According to Adorno: 'thought as such...is an act of negation, of resistance to that which is forced upon it' (1966/ 1981a, p. 19). More indirect communication, the use of montage, and the poetic all form literary conditions in which insights may be caught, as it were, 'out of the corner of [the] eye or even at the corner of the text' (Goehr 2005, p. xxxii). In the final aphorism of

\footnotetext{
${ }^{1}$ In a letter to Benjamin, he says: 'You are only too well aware how intimately the significance of the work [Benjamin's essay on Kafka] is bound up with its fragmentary character' (Adorno and Benjamin 1999, p. 67). Adorno would have been no supporter of 'plain English'—or plain German-for that matter. In Minima Moralia, he writes: 'only the word coined by commerce, and really alienated, touches [people] as familiar. Few things contribute so much to the demoralization of intellectuals. Those who would escape it must recognize the advocates of communicability as traitors to what they communicate' (p. 101). Elsewhere in the same text, he says: 'dialectic advances by way of extremes, driving thoughts with the utmost consequentiality to the point where they turn back on themselves...' (p. 86). It is unfortunate that this is not widely acknowledged in cultural studies; it is easy to disagree with Adorno when isolated texts are taken as 'representative example[s]' of his thought (see, for example, Storey 2006, p. 66).
} 
Minima Moralia (1951/2005), he describes this off-kilter view: 'Perspectives must be fashioned that displace and estrange the world, reveal it to be, with its rifts and crevices, as indigent and distorted as it will appear in the messianic light' (p. 247). Adorno's powerful and intriguing critique illuminates a way of comprehending what is happening now in cultural education, and perhaps venturing some thoughts on how we might proceed, but it is not a formula or system which can be adopted, as it were ready to wear.

Adorno's work on the 'culture industry' is relatively well known. Less well known are his works of public philosophy, which mainly take the form of radio broadcasts. These public lectures are often different in tone from his other writings and they focus strongly on the immediate lived experience of people who are puzzling how to make sense of the catastrophe that had befallen Germany and much of the rest of the world and also struggling to make a society in which life is worth living. One group to whom he repeatedly turns his attention is teachers and in this he draws on his experiences of interviewing and examining candidates for entry to the profession. At this time, a major concern amongst the Allies was the denazification of educators in Germany and Austria (Tent 1982). Adorno returned to Germany as a US citizen and the Institute for Social Research was re-established in Frankfurt with the support of the US government as part of a programme of national re-education. But, Adorno addresses bigger issues about the selection and education of teachers, their role in society and the purpose of education. Throughout, the concept of culture is central.

\section{Culture Industry}

The idea of the 'culture industry' is an analysis of culture that could be misunderstood and caricatured as somewhat hysterical elitism in which Hollywood is bad and Schoenberg is good. In this respect, Adorno sometimes did not help himself, with his bilious dismissals of jazz, the Beatles and 'protest music' of the $1960 \mathrm{~s}$. A selective reading might indicate an attack primarily on popular culture since it presents more obviously as an industry, something that is produced and sold to a market, than does so-called high culture. But, Adorno explicitly denied this interpretation of his analysis (1963/1975, p. 98). The culture industry imposes 'the profit motive naked onto cultural forms' (1963/1975, p. 99). This applies to both 'light' and 'serious' art in equal measure: 'The differences in the reception of official 'classical' music and light music no longer have any real significance. They are still manipulated for reasons of marketability' (1938/1982, p. 35). Cultural events that have no cost have already been paid for by the working classes: 'all culture shares the guilt of society. It ekes out its existence only by virtue of injustice already perpetrated in the sphere of production' (1967/1981b, p. 26; see also 1944/1997, p. 159). For this reason, Adorno dismisses as superficial cultural criticism that merely bemoans the commodification of culture as though underneath the layer of capital there is a pure undamaged art form. Though he understands art as autonomous and as having critical purchase on society, including recalcitrant popular forms and the 'advanced product [that] has renounced consumption' (1938/1982, p. 35), he argues that the commodification of art causes it to be stripped of these qualities and to serve the goal of increasing capital both by the direct exchange of money and also by causing people to accept the tenets and processes of capitalism in exchange for transitory pleasure (1944/1997, p. 144).

At times, Adorno indicates that the possession of culture by the monopolistic, totalizing action of capitalism is complete-all autonomy, conflict and resistance are 'liquidated' or 
'eliminated'; 'All difference degenerates to a nuance in the monotony of supply' (1947/ 1991, p. 74, 1963/1975, p. 99, 1967/1981b, p. 21). His most famous statement of despair about culture, his Kulturpessimismus, was this:

Even the most extreme consciousness of doom threatens to degenerate into idle chatter. Cultural criticism finds itself faced with the final stage of the dialectic of culture and barbarism. To write poetry after Auschwitz is barbaric.... Absolute reification ... is now preparing to absorb the mind entirely. (1967/1981b, p. 34)

Adorno's despair about culture remained unassuaged to the end: 'all post-Auschwitz culture, including its urgent critique, is garbage' (1966/1981a, p. 367). But, in other texts Adorno's exaggerated polemical style does give way to something more nuanced and he concedes the possibility of a not completely reified culture, one that does at least appear to challenge and resist.

\section{Culture and the 'Unity of Opposites'}

The 2009 Christmas number one in the UK music chart was a fairly amusing surprise. After an online campaign to ensure that the winner of the X-Factor did not achieve the near-guaranteed number one slot, the rock band, Rage Against the Machine outsold other contenders with a song that has the refrain: 'FUCK YOU I WON'T DO AS YOU TELL ME!'. The question is: should we believe its professed insubordination or should we dismiss it as self-deception 'in the service of success'? (1938/1982, p. 33). In this instance, one of the musicians ably fielded the question in an interview for the Los Angeles Times: 'When you live in a capitalistic society, the currency of the dissemination of information goes through capitalistic channels.... We're not interested in preaching to just the converted (Hilburn, 1996). Without doubt, the campaign was intended to be a rejection of the total commercialization the X-Factor represents.

Adorno admits that there was rarely, if ever, a 'pure' form of art, in which financial considerations played no part: 'Pure works of art, which deny the commodity society by the very fact that they obey their own law were always wares all the same' (1944/1997, p.157). But, the fact that something is paid for does not entail that it is exclusively a commodity - the commodification can be indirect and secondary. He cites the example of Beethoven as 'the most outstanding example of the unity of those opposites, market and independence' (1944/1997, p. 158). This idea of the 'unity of opposites' is key to understanding Adorno's position. The unity in question is not a 'liquidation of conflict' or a stable and motionless balanced difference but rather a vital movement of ideas in response and counter-response. Conflict within a work of art comes from its relation to practical lived experience: 'no authentic work of art...has ever exhausted itself in itself alone, in its being-in-itself. They have always stood in relation to the actual life-process of society from which they distinguished themselves' (1967/1981b, p. 23). In contrast, the elimination of conflict within the work of art indicates the sundering of this connection and the fetishization of culture, which becomes like predigested baby food (1947/1991, p. 67). Identitarian thinking is the collapse of the particular into the universal, resulting in a reified culture which feeds us an unvarying world of fungible individuals; it replicates faithfully the pre-existing standards, without startling or challenging or offering a stimulus to imagine something different or better. Laminated familiarity, hyper-reality, paper-thin variety, false immediacy—They are just like us! Only better! The presence of conflict leads 
to immanent criticality and this is what Adorno holds to be 'true' culture: 'culture and criticism are intertwined. Culture is only true when implicitly critical.... Criticism is an indispensable element of culture which is itself contradictory' (1967/1981b, p. 22). Adorno's rejection of the notion that culture is a good per se is based on this distinction between reified (pseudo) culture and true culture, not on a hierarchy of high and low culture.

The notion of true culture as it has so far been described may seem to advocate some kind of social realism in art, but this is misleading. To understand its import better, we need to turn to Adorno's aesthetic theory and to the theme of mimesis. In Dialectic of Enlightenment Adorno and Max Horkheimer put forward the thesis that the instrumental reason so evident in late modernity is not a subspecies or distortion of formal reason, but rather its sublation: its unfolding or unveiling. This is how we can understand the reach of instrumental thinking as the dominance of objectifying thought, that relation to the world that is functional, aetiological and inverts the primacy of ends to means, and that requires the reductive categorization of mathematical-scientific thinking in order to predict, control and dominate the natural world, including our social relations. We feel safe in the world because we have conquered nature, or so we thought until we could no longer ignore the evidence of the destruction wrecked by our untrammelled supremacy, our 'open insanity' (1944/1997, p. 54). But, this is merely the somatic pathology of enlightenment. Adorno and Horkheimer point to the extension of this reifying tendency to subjectivity itself. This means the renunciation of what they call 'spirit', those parts of human experience that are not systematic, controllable or predictable, that are indeterminate, sensual, or that are part of our experience because of their absence or silence. This is the living mind and is easier to destroy than it is to describe in words: 'The subjective spirit which cancels the animation of nature can master a despiritualized nature only by imitating its rigidity and despiritualizing itself in turn' (1944/1997, p. 57). Reified consciousness, then, is the ultimate achievement of the over-administered world.

Even if it were possible, and it is not, this account does not advocate some kind of return to pre-enlightenment rationality, a re-enchanted, re-spiritualized world. And, it is not what Hegel describes as a 'pertulant zeal to save mankind from its absorption in the sensuous, the vulgar and the singular' (PG.8). What is it does do is set the scene for an enquiry as to the location of spirit in late modernity. Quite obviously, the very fact that we can speak of the totalizing tendency of reification, seen across all spheres of life, from our intimate family relations to the marketization of education, means that the process is not complete.

The term Adorno chooses to describe the locus and activity of this site of resistance is mimesis, a concept that is aptly resistant to efforts to comprehend it. It seems quite the wrong term from the start because it is this logical principle of identity/non-contradiction that itself lays down the identity thinking of exchangeability underpinning late modernity. Why does Adorno choose a term that signifies 'making like' to disrupt this reductive equivocation? In fact, he uses it in several quite distinct senses. Firstly, there is the mimesis of the natural world that is part of magical, pre-rational human activity: the prehistory of art. Then, there is also the mimesis that supplants this first kind with reason: 'It is itself mimesis: mimesis unto death. The subjective spirit which cancels the animation of nature can master a despiritualized nature only by imitating its rigidity and despiritualizing itself in turn' (Adorno 1997, p. 57) This can be related to what I have so far called reified or pseudo-culture.

The final usage is the mimetic moment that is in the dialectic between these first two uses: 
The survival of mimesis, the non-conceptual affinity of the subjectively produced with its unposited other, defines art as a form of knowledge and to that extent as 'rational'. For that to which the mimetic comportment responds is the telos of knowledge, which art simultaneously blocks with its own categories. Art completes knowledge with what is excluded from knowledge and thereby once again impairs its character as knowledge, its univocity. (1997, p. 74)

Even if we can accept the multivalency of this term, this last sense is surely still elusive. It places art in a space between the magically animated pre-rational world and the totally administered world, in a sense between life and death. Art bears witness to non-conceptual knowledge; correspondingly mimesis is what Wellmer (2012) summarizes as the 'designation for the sensually receptive, expressive, and communicative modes of behaviour of the living' (p. 51). Huyssen (2000) describes how the 'dimensions of mimesis lie outside linguistic communication-locked in silences, repressions, gestures and habits' (p. 72). Again, Sinha (2000) noting that 'the non-significative character of language is given precedence over the significative or communicative aspect of language' in Adorno's conceptualization of mimesis because the mimetic moment in art 'expresses expression itself and nothing else'. The elusive nature of this sense of mimesis is apt because it concerns elusive knowledge, and here Adorno turns to the theological trope of redemption, describing such a perspective as prefiguring the world as it will be revealed 'one day in the messianic light' (2000 p. 153). The mimetic aspect of art resists the 'destruction of the subject' under the conditions of modernity and redeems the living spirit: this is social emancipation.

\section{Adorno and Education: The End of Education and Teachers' Work}

For Adorno art and philosophy converge to occupy the same space: 'two spheres of the spirit' (Wellmer 2012, p. 51). The recent fate of philosophy can be compared to that of culture in that it has become separated from 'concrete societal goals' and has retreated instead to content-less specialisms. Adorno cites Hegel's proposition that 'philosophy is its own time comprehended in thought'. If contemporary culture embodies history, then philosophy relates to that culture as resistance, as critique of the present state of the world (1962/1998b, p. 14). So, when he proposes that criticism is intertwined with culture, he is describing the relationship of philosophy to culture. In making this connection, it becomes possible to think of culture in relation to what Adorno asserts to be the end of education and the role of the teacher.

One of Adorno's most well-known statements about education is from his essay 'Education After Auschwitz' which was first delivered as a radio broadcast in 1966, which he begins with these words:

The premier demand upon all education is that Auschwitz not happen again .... Every debate about the ideals of education is trivial and inconsequential compared to this single ideal: never again Auschwitz. It was the barbarism all education strives against.... and barbarism continues as long as the fundamental conditions that favoured that relapse continue largely unchanged. That is the whole horror. (1967/ 1998c, p. 191) 
Elsewhere, in the same year, he describes this 'premier demand' as a 'new categorical imperative' on the whole of mankind (1966/1981a, p. 365). The education that Adorno means is specifically 'education toward critical self-reflection' (1967/1998c, p.193). He again returns to the idea that the prevailing civilization exerts pressure on the individual to conform, to identify blindly with the collective, so destroying any power of resistance (1967/1998c, p. 197). He makes some rather odd proposals in this essay and his analysis is conspicuously eclectic but the basic message is consonant with ideas he developed elsewhere, for example in the 1969 radio broadcast with Hellmut Becker, a prominent German educationalist, transcribed in 'Education for Maturity and Responsibility' (1997) where he speaks of 'an education for protest and resistance' (p. 31). Nicht mitmachen (do not join in/be out of step), a favourite slogan of Adorno and his colleagues in the Institute for Social Research from its early days (Jay, 1973, p. 321), could well be adopted as a catchphrase of Adorno's vision for education. But, he is by no means underestimating the task he is setting. To be out of step means being at odds with the dominant consciousness, which is fully equipped with an armoury of everything from sneering ridicule to judicial and military force. The forces that would make possible the 'relapse' are ascendant and hope is thin and fragile. The essay begins boldly but ends with a little shrug: 'against this, however, education and enlightenment can still manage a little something' (1967/1998c, p. 204).

So, what does Adorno say about teachers? Mass education is perhaps the most powerful institutional tool in shaping and changing how people think and behave. He was conscious of the role played by teachers in the Nazi era and was sensible of the importance of early childhood experiences. In his 1961 lecture, 'Philosophy and Teachers', he reflects on the experience of examining candidates for the profession on their chosen area of philosophy. Some of his descriptions of encounters with students in this context are frankly funny, though his intention is emphatically not to mock them or to be unkind. In reflecting on the students' ability to respond to questions he makes a distinction between the understanding of the teacher's role as that of 'specialized technician' and the notion of the teacher as an intellectual. He explains the identity of the intellectual in this way:

Whether someone is an intellectual or not is manifested above all in his relationship to his own work and to the societal totality of which it is part. This relationship ... is what constitutes the essence of philosophy in the first place. (1962/1998a, pp. 21-22)

The students who seem to have caused him the greatest vexation were not unintelligent or lazy. They read the requirements of the task and followed them with precision; they studied hard to acquire the information that they hoped would enable them to pass their examination. What they did not seem to be able to do was to think, to respond to what they had read and to care about its meaning. For a teacher to be an intellectual, she does not have to have a great mass of facts at her fingertips; Adorno is quite scathing about this kind of knowledge, describing it as a "patchwork of acquired-which most often means memorized-facts' (1962/1998a, p. 27). Rather it is the connectivity between the subject matter-what is known — with 'the societal totality' that matters, and it is this that makes an individual cultured. The capacity to make such connections is one thing that makes it possible to cultivate others. Without the previous consideration of culture in terms of resistance and critique, it would be difficult to understand Adorno's intention here: a teacher should be someone who 'has culture' and this is indicated by his being able to demonstrate an interest in making connections and comparisons, in questioning what happens to be the case, and being personally entangled in the immanent criticality of the situation. 
Adorno struggles to describe how such capabilities develop: he admits that there are no rules and no university courses that guarantee their acquisition. In a distinctively Hegelian series of expressions, he says that it is more to do with an open mind and an ability to engage and tarry with what is other and unfamiliar (1962/1998a, p. 28). He goes on, evidently with some hesitation, to venture that in fact 'culture requires love' but this uncharacteristically affirmative and simple suggestion is not explained here. What might he mean?

In a recent examination of the place of intimacy in Adorno's thought, Macdonald (2011) describes how Adorno rejects the Kantian definition of autonomy in terms of rational interiority, whilst accepting the idea that maturity is achieved by means of self-liberation from heteronomy. To insist on a self-legislating subject is to throw out the baby with the bath water. Thinking for oneself does not entail the abandonment of the context which has called forth the thinking in the first place, rather moral thinking is 'squeezed out of "matter" with which moral philosophy did not want to dirty its hands' (1966/1981a, p. 243). Intimacy is Adorno's corrective to Kant's concept of autonomy because there are 'irreplaceable faculties which cannot flourish in the isolated cell of pure inwardness, but only in live contact with the warmth of things' (1951/2005, p. 43; Macdonald, 2011). 'Live contact' is described as a non-coercive gaze and as 'differentiation without domination'; this is in stark contrast to the Enlightenment rationality which Adorno and Horkheimer condemn as having the sole aim of dominating nature and other human beings. What holds together this 'unity of opposites' is the ethical substance of Adorno's thought. There is no morality without the 'material'; it is the ordinary and messy reality of life that gives rise to the need for moral thinking. So, although Adorno emphatically endorses Kant's idea of autonomy as intellectual and moral maturity, his morality has to be to be mired in the particularity of the everyday, the sensual, communicative living experience of non-reified consciousness.

The suggestion that 'culture requires love' is comprehensible in the context of the activity of teaching. Teaching is a hopeful activity, which demands resilience in the face of setbacks and trust in the possibility of future maturation. To describe the values and commitments inherent in the role of the teacher as love goes beyond the knowledge, skills and processes involved in teaching, and it starts to illuminate what drives and maintains the relationship of teacher and pupil. Adorno quite rightly says that 'love cannot be summoned in professionally mediated relationships' (1967/1998c, p. 202), but this does not mean that love ought not to be present in these relationships. A good teacher warmly identifies with her pupils and is far from indifferent to what happens to them, and, by implication, what happens to the world they will occupy, make and inherit. The coldness that Adorno believes has infected everyone, more or less, through instrumental rationality - the very logic of capitalism-made Auschwitz possible. But, if the premier demand upon all education is that Auschwitz not happens again, we have to trust that 'live contact with the warmth of things' can happen in the university, the school and the classroom. Cultural education has the potential to be where children can encounter the richness and variety of human experience through the arts and also through personal contact with the beliefs, values and traditions of different people. Crucially, it is also where children can generate culture, renew tradition and express their own experiences, thoughts and feelings. 


\section{Conclusion}

Louis MacNeice's 'Snow', quoted at the beginning, explores the experience of sudden and unexpected juxtapositions. In this poem, a room is suddenly transformed when snow starts to fall, resulting in an unlikely, unseasonal meeting between the snow and the huge pink roses sitting in the bay window. The exhilaration of the experience of the "collateral and incompatible' is tempered by a tension and a sober sense of foreboding - caused by the distance between the two elements, which at the end of the poem seems far greater, an unbridgeable gulf. But, the roses and snow do meet against the glass and in the poem itself. MacNeice calls the condition of plurality 'World', a proper noun that hypostasizes this condition as a personality- 'gay' and 'spiteful' and capricious. These characteristics show World alive. It is the liveliness and ambivalence that we find also in Adorno's conception of culture and his requirement for 'live contact with the warmth of things' against permeating coldness and indifference. This one theme in MacNeice's poem is particularly apt for helping develop a conceptual landscape for the plural and various, and why they are troublesome and how they might be important for education and culture. Cultural education happens in a complex and contested space. Different understandings of culture, the artistic, the humanist and the anthropological, are all evident to different degrees in various policy contexts. The plurality of culture and of cultures is a problem but also a site where something distinctive and crucial happens: resistance or critical self-reflection as a core aim of education takes place in a context of rich experience of incorrigible plurality.

Adorno rejects the notion that culture is a good in itself. His proposal that 'true' culture is critical or philosophical departs from concern about whether a cultural practice is somehow worthwhile because of its intrinsic or instrumental value. Instead attention is on the way in which cultural participation becomes the site where we question what happens to be the case and resist heteronomous ways of thinking. Cultural education requires an environment in which both senses of culture converge as the objects of attention: as creative endeavour and as a distinctive way of life. The attention is not goal-directed, that is, merely instrumental in its intent, but rather it has what Iris Murdoch describes as a concern for the individual and this concern is expressed in 'an attentive patient delay of judgement, a kind of humble agnosticism, which lets the object be' (Murdoch 1992, p. 377). MacNeice's 'Snow' fixes a moment of transport that does not climax in possession or resolution, which would be quite right when thinking about cultural education because this is not an argument for cultural assimilation. Much as Adorno disliked the term 'encounter', because its use is so often hackneyed and vacuous, this does seem to be the appropriate word. Cultural education involves a meeting; it entails risk and openness; and it may not yield satisfaction. Like the snow and roses, it could be that we look but not touch. Henry Giroux challenges the doctrine of 'normative pluralism', which gives us the modern multicultural educational practice that aims to reduce intercultural tension, promote kindly tolerance and enhance mutual understanding (1988, pp. 94-97). These intentions are laudable at least in so far as to desire their opposites would be reprehensible. But, if it tends to make unimportant those deep differences that do exist, and to turn the gaze away from uncomfortable truths about relations of power and privilege, it will effectively close the critical space opened out in cultural education. In this respect, Adorno anticipates Giroux's point and help us to form an understanding of how culture and cultural education embody rather than resolve difference, tension and conflict.

The Scottish Curriculum seeks to couple culture and history with a view to fostering exploration, reflection and the solving of problems (Education Scotland 2013, p. 2). For 
these things to happen what is needed is richness of experience: plurality and variety. A broad range of cultural experiences is good because it is harder for a person who is thus experienced to avoid the idea that things could be otherwise than how they are and to acquire 'the ability to see in this world the possibility of something different and better' (French and Thomas 1999, p. 3). On the other hand, the monochrome cultural experience of an unvaried diet of commercially conceived disposable dross does not provide the dynamic of the dialectical relationship with the societal totality of which it is part, nor is it possible to unveil any inner dynamic of market and independence. On its own it is rubbish. This is, in part, an argument for the inclusion of what Moffat and Riach have recently called the 'wayward artists and writers' in the school curriculum. These are the people who have pre-eminently rejected the 'mortmain of the uniform identity that insists on any single story dominating others' (2014, loc.93). Helmut Becker in discussion with Adorno in 1969 advocated the 'dissolution of an education system based on a fixed canon, and the replacement of this canon by a very varied curriculum' for precisely this reason (p. 30). But, the rejection of uniform identity does not entail that we need be embarrassed to have or seek an identity; as the same authors say elsewhere: 'We are committed to an openness of mind and the capacity for self-extension to which human nature is healthily prone... But we should never neglect or scorn the work of our own people' $(2008, \mathrm{p}$. x). The idea that a nation can sidestep the idea of national identity in considering cultural education is dangerously mistaken. There is also a thin line between tolerance and indifference. Children require opportunities to connect, contrast and compare: a significant challenge in any content-orientated curriculum and a major challenge also to a profession already burdened with increasingly complex demands.

Cultural education is in this way not in the slightest to be regarded as a decorative addon to the serious business of education but is at the heart of all worthwhile educational effort. Adorno rightly observes that there is no rule or recipe for 'achieving culture', and no course of study that ensures a person will become cultured in the sense he uses the word, since the quality of the experiences depend on the comportment of the individual: their curiosity and openness, and, most importantly, the 'live contact with the warmth of things' that can happen in the classroom community, where profound indifference to the fate of others is not regarded as normal or acceptable. Reasonably, cultural education may 'still manage a little something' by providing the objects of attention and expecting such things to happen in a context where love and resistance are the currency.

Open Access This article is distributed under the terms of the Creative Commons Attribution 4.0 International License (http://creativecommons.org/licenses/by/4.0/), which permits unrestricted use, distribution, and reproduction in any medium, provided you give appropriate credit to the original author(s) and the source, provide a link to the Creative Commons license, and indicate if changes were made.

\section{References}

Adorno, Theodor W. 1975. Culture industry reconsidered. New German Critique 6: 12-19. (original work published 1963).

Adorno, Theodor W. 1981a. Negative dialectics. New York: Continuum. (original work published 1966). Adorno, Theodor W. 1981b. Cultural criticism and society. In Adorno, T. W. Prisms. (trans: Weber, S. S.). Cambridge, MA: MIT Press, 17-34. (original work published 1967).

Adorno, Theodor W. 1982. On the fetish-character in music and the regression of listening. In The essential Frankfurt School reader, ed. A. Arato, and E. Gebhardt. New York: Continuum. (original work published 1938). 
Adorno, Theodor W. 1991. The schema of mass culture. In The culture industry: Selected essays on mass culture, ed. J. M. Bernstein. London: Routledge. (original work published 1947).

Adorno, Theodor W. 1997. Aesthetic theory. London: Bloomsbury. (original work published 1970).

Adorno, Theodor W. 1998a. Philosophy and teachers. Critical models: Interventions and catchwords. New York: Columbia University Press. (original work published 1962).

Adorno, Theodor W. 1998b. Why still philosophy? Critical models: Interventions and catchwords. New York: Columbia University Press. (original work published 1962).

Adorno, Theodor W. 1998c. Education after Auschwitz. Critical models: Interventions and catchwords. New York: Columbia University Press. (original work published 1967).

Adorno, Theodor W. 2005. Reviewing Adorno: Public opinion and critique. In Theodore W. Adorno. Critical models: Interventions and catchwords, ed. L. D. Kritzman (trans: Pickford, H. W.). NewYork: Columbia University Press. (original work published 1963/69).

Adorno, Theodor W., and Max Horkheimer. 1997. Dialectic of enlightenment. London: Verso. (original work published 1944).

Adorno, Theodor W. and Hellmut Becker. 1997. Education for maturity and responsibility. (trans: French, Robert, Thomas, Jem and Weymann, Dorothee) History of the Human Sciences 12(3): 21-34.

Adorno, Theodor W. and W. Benjamin. 1999. Theodore W. Adorno and Walter Benjamin: The complete correspondence 1928-1940, ed. H. Lonitz (trans: Walker, N.). Cambridge: Polity Press.

Ancien, Delphine, Mark Boyle, and Rob Kitchen. 2009. The Scottish diaspora and diaspora strategy: Insights and lessons from Ireland. Edinburgh: Department of Geography and National Institute for Regional and Spatial Analysis, National University of Ireland.

Beveridge, Craig, and Ronald Turnbull. 1989. The eclipse of Scottish culture. Edinburgh: Polygon.

Clark, Peter. 2014. Report into allegations concerning Birmingham schools arising from the 'Trojan Horse' letter. London: Department for Education.

Craig, Carol. 2003. The Scots' crisis of confidence. Glendaruel: Argyll Publishing.

Department for Education (DfE). 2013. The national curriculum in England.

Education Scotland. 2013. Curriculum for excellence briefing: learning about Scotland. Edinburgh: Education Scotland.

Forgan, Liz. 2013. A farewell to arts (final speech as Chair, Arts Council England).

French, Robert, and Jem Thomas. 1999. Maturity and education, citizenship and enlightenment: an introduction to Theodor Adorno and Hellmut Becker, 'Education for maturity and responsibility'. History of the Human Sciences 12(3): 1-19.

Giroux, Henry A. 1988. Critical pedagogy, cultural politics, and the discourse of experience. In Teachers as intellectuals. Westport: Bergin \& Garvey.

Hegel, Georg Wilhelm Friedrich. 2008. Phenomenology of Spirit. (trans: Pinkard, T.). (original work published 1807). Retrieved from http://www.web.mac.com/titpaul/Site/Phenomenology_of_Spirit_ page.html

Goehr, Lydia. 2005. Reviewing Adorno: Public opinion and critique. In Theodore W. Adorno. Critical models: Interventions and catchwords. NewYork: Columbia University Press.

Herald Scotland. 2012. Leading artists letter to creative Scotland Chairman.

Henley, Darren. 2012. Cultural education in England. Department for Education.

Huyssen, Andreas. 2000. Of mice and mimesis: Reading spiegelman with Adorno. New German Critique 81: 65-82.

Hyslop, Fiona. 2013. Past, present and future: Culture and heritage in an independent Scotland. [transcript]. Talbot Rice Gallery, Edinburgh University. Retrieved from http://www.scotland.gov.uk/News/ Speeches/Culture-Heritage05062013.

Jay, Martin. 1973. The dialectical imagination: A history of the Frankfurt School and the Institute of Social Research, 1923-1950. Berkeley: University of California Press.

McCleery, Alison, Alastair McCleery, Linda Gunn, and David Hill. 2008. Scoping and mapping intangible cultural heritage in Scotland, final report. Edinburgh: Napier University Centre for Cultural and Creative Industries.

Macdonald, Iain. 2011. Cold, cold, warm: Autonomy, intimacy and maturity in Adorno. Philosophy and Social Criticism 37(6): 669-689.

McMillan, Joyce. 2012. Start again, there's plenty of talent around. Scotsman Newspaper.

Miller, Maria. 2013. Testing times: Fighting culture's corner in an age of austerity. Keynote Arts Speech British Museum. Retrieved from: https://www.gov.uk/government/speeches/testing-times-fightingcultures-corner-in-an-age-of-austerity.

Moffat, Alexander, and Alan Riach. 2014. Arts of independence: The cultural argument and why it matters most. Edinburgh: Luath Press.

Murdoch, Iris. 1992. Metaphysics as a guide to morals. London: Chatto and Windus. 
Sinha, Amresh. 2000. Adorno on Mimesis in Aesthetic Theory. In In practice: Adorno, critical theory and cultural studies, ed. Holger Briel, and Andreas Kramer, 145-159. Bern: Lang.

Storey, John (ed.). 2006. Cultural theory and popular culture: A reader, 3rd ed. Harlow: Pearson Education. Tent, James F. 1982. Mission on the Rhine: Reeducation and denazification in American-occupied Germany. Chicago: University of Chicago.

Wellmer, Albrecht. 2012. Adorno, advocate of the nonidentical: An introduction'. Current Perspectives in Social Theory 30: 35-60. 